\title{
ВИКОРИСТАННЯ МЕТОДУ ВНУТРІШНЬОВЕННОГО ВВЕДЕННЯ РОЗЧИНУ ПЕРЕКИСУ ВОДНЮ ДЛЯ ЛІКУВАННЯ ПАЦІЄНТІВ З ВАРИКОЗНИМ РОЗШИРЕННЯМ ВЕН НИЖНІХ КІНЦІВОК
}

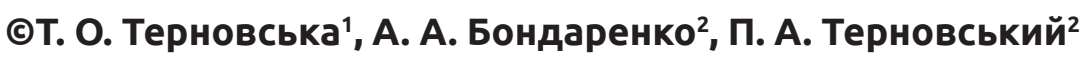 \\ мОз України, Медичний кабінет \\ Фізична особа - підприємець Терновська Тамара Олексіївна, м. Кропивницький ${ }^{7}$ \\ Донецький національний медичний університет ${ }^{2}$
}

РЕзЮМЕ. Варикозна хвороба нижніх кінцівок відома здавна, проте і до сьогодні вона залишається надзвичайно актуальною і значно погіршує якість життя пацієнтів.

Мета - зробити короткий огляд запропонованого нами методу лікування варикозного розширення вен 3 метою відновлення функції неспроможних клапанів вен. На конкретних клінічних випадках показати ефективність і доступність запропонованої методики в медичній практиці.

Матеріал і методи. Діагностику проводили з використанням апарата для ультразвукового дуплексного сканування нижніх кінцівок My Lab 40, для лікування застосовували метод внутрішньовенного введення розчину перекису водню за розроблено нами методикою [9]; результати аналізу джерел вітчизняної і зарубіжної наукової літератури та зареєстрованих патентів.

Результати. Позитивний результат лікування конкретних пацієнтів підтверджений методом ультразвукового дуплексного сканування (УЗДС). Клінічні результати лікування хворихна варикозне розширення венпідтверджують можливість використання даного методу, поряд з іншими щадними методами лікування варикозної хвороби, в клінічній практиці.

Висновки. Запропонований та запатентований нами спосіб відновлення функції неспроможних клапанів вен $\epsilon$ ефективним для лікування пацієнтів з варикозним розширенням вен та запобігання виникненню рецидиву захворювання. Лікування за нашим методом дає прогнозовані позитивні результати при вмілому користуванні і урахуванні протипоказань.

КЛючОВІ СлОВА: варикозне розширення вен; лікування; клапани вен; перекис водню.

Вступ. Варикозна хвороба вен нижніх кінцівок відома здавна, проте й до сьогодні вона залишається надзвичайно актуальною, значно погіршуючи якість життя людей. За деякими даними, вказана патологія наявна у кожного четвертого жителя планети. Свій внесок у поширення цього захворювання зробили зміни, пов'язані з сучасним стилем життя людей. Це переважно малорухомий спосіб життя, сидяча робота або робота, пов'язана з тривалим статичним навантаженням, шкідливі звички тощо. Відомо також, що ця хвороба частіше трапляється в жінок, ніж у чоловіків [1].

За даними інших досліджень, 8 із 10 людей в популяції страждають на варикозну хворобу в тій чи іншій формі [2].

Варикозну хворобу часто ускладнюють трофічні виразки, тромбози та емболії, що призводить до значного погіршення якості життя хворих. Особливу групу ризику виникнення варикозної хвороби складають вагітні жінки, що обумовлено гормональними змінами у цей період, механічними, циркуляторними та іншими чинниками.

Хвороба характеризується варикозною трансформацією судинної стінки підшкірних вен, що призводить до зниження їх функціональних можливостей та порушення кровообігу за рахунок дисфункції м'язової венозної помпи та неспромож- ності венозних клапанів, розвитку патологічних вертикальних і горизонтальних рефлюксів крові, набряку та лімфостазу периферійних відділів кінцівок [3].

Незважаючи на наявний на сьогодні величезний арсенал методів лікування цієї патології, препаратів і способів лікування [17], повного контролю над хворобою і регресу симптомів домогтися не вдається. Тому постійно триває пошук нових способів і методів лікування хворих на варикозне розширення вен нижніх кінцівок.

Матеріал і методи дослідження. У більшості хворих неспроможність клапанів обумовлена розширенням вени в ділянці розташування клапана [10-15]. Для запобігання ретроградному рефлюксу крові по венах розроблені численні способи лікування, спрямовані на звуження патологічно розширеної ділянки вени, в якій розташовані клапани, що приводить до зникнення їх вторинної неспроможності. Наприклад, накладання циркулярного шва з захопленням адвентиції; накладання циркулярної муфти з ізольованого фрагмента аутовени, чи вільного фрагмента підшкірної вени, широкої фасції стегна, синтетичного матеріалу, каркасної спіралі з лавсану чи танталу [13]. Ці способи зазначені, як аналоги заявленого нами способу. Найближчим до запатентованого 
Огляди літератури, оригінальні дослідження, погляд на проблему, ювілеї

нами способу відновлення функцій неспроможних клапанів вен $є$ спосіб корекції відносної клапанної недостатності глибоких вен нижніх кінцівок шляхом перивазального введення поліакриламідного гелю у вигляді «муфти», двома способами. За першим способом здійснюється хірургічний розтин і під візуальним контролем вводиться поліакриламідний гель. При другому способі під ультразвуковим контролем здійснюють пункцію і вводять поліакриламідний гель в перивазальну ділянку. "Муфта" запобігає надмірному розширенню вени, i, таким чином, відновлюється функція клапана [4]. Недоліком відомого прототипу $\epsilon$ те, що в організм людини вводиться чужорідна речовина. Причому при введенні речовини за першим способом відбувається травматизація тканин, необхідне знеболювання, наявний значний косметичний дефект в післяопераційному періоді. Крім того, прототип розрахований лише на лікування клапанів глибоких вен нижніх кінцівок.

3 метою поліпшення лікування пацієнтів ми розробили більш доступний, менш травматичний спосіб [9], завдяки якому забезпечується відновлення функції неспроможних клапанів вен поверхневої, глибокої венозної систем та поверхнево-глибоких венозних співусть. Запропонований нами метод лікування варикозної хвороби з допомогою розчинів $\mathrm{H}_{2} \mathrm{O}_{2}$ належить до галузі медицини ангіології і може бути використаний для лікування варикозно розширених вен кінцівок та відновлення функції неспроможних клапанів вен. В медицині відомі приклади використання розчину перекису водню для оздоровлення організму і лікування каузалгії при ампутації нижніх кінцівок шляхом внутрішньосудинного введення [5-7].

Згідно з запропонованим нами методом, корекцію відносної клапанної недостатності вен здійснюють після попереднього маркування проекції неспроможних клапанів вен під контролем ультразвукового дуплексного сканування шляхом внутрішньовенного введення безпосередньо в ділянки вен з неспроможними клапанами та / або поблизу них розчинів перекису водню з концентрацією 0,0075-0,15 \% в об'ємі 50-600 мл зі швидкістю 1-15 мл за хвилину. За показаннями використовують компреси із настойкою шкірки плодів каштану кінського і кореневища аїру та спеціальну фізкультурну вправу.

За тиждень до лікування пацієнт повинен відмовитися від споживання алкоголю, куріння, вживати переважно рослинну їжу без солі і цукру та достатню кількість води (30 мл на кг маси тіла на добу). Обов'язковою умовою успішного лікування $\epsilon$ дотримання вказаної дієти за тиждень до, в процесі, і впродовж тижня після лікування. При наявності трофічних змін у нижніх кінцівках (ліподермато- склероз, пігментація, виразка наявна або в анамнезі) дотримання вказаної дієти має бути довічним.

Сеанси лікування проводяться щодня, амбулаторно. Кожному хворому підбирається схема лікування, визначається індивідуальна швидкість введення основних компонентів і концентрація лікарського розчину, гомеопатичні препарати i, залежно від стадії розширення вен, компреси відповідного складу [16], супровідне медикаментозне лікування. При підборі лікування враховується стан здоров'я кожного конкретного пацієнта.

$€$ певні захворювання і стани, при яких лікування даним методом не проводиться. Зокрема це наявність в анамнезі кодування від алкоголю та наркоманії; дисплазія, аномалія розвитку судин шиї і голови; атеросклероз судин шиї і голови; онкозахворювання з метастазуванням; анемія (гемоглобін менше 100 г/л); гемофілія; неспецифічний виразковий коліт у гострій фазі захворювання; артеріальний тиск нижче 80 мм рт. ст.; вагітність, годування груддю; афібриногенемія; капіляротоксикоз; тромбоцитопенічна пурпура; ДВЗ-синдром; бешиха наявна або в анамнезі (оскільки при лікуванні може бути загострення захворювання у вигляді шкірних проявів або флебіту); аритмія; психічні захворювання; флебіти, тромбофлебіти; діаметр розширеної вени 10 мм і більше; вживання гормонів, в тому числі протизаплідних засобів. Наявність запальних процесів $\epsilon$ відносним протипоказанням [18].

Кожному пацієнту підбирають індивідуальні концентрацію, об'єм, швидкість введення розчину перекису водню. Переносимість пацієнтом перекису водню перевіряють шляхом внутрішньовенного крапельного введення його розчинів 0,0075-0,015 \% в об'ємі 50-200 мл зі швидкістю 0,1-5 мл за хвилину. При добрій переносимості вводять розчин перекису водню з концентрацією 0,0075-0,15 \% в об'ємі 50-600 мл зі швидкістю 1-15 мл на хвилину безпосередньо в ділянки вен 3 неспроможними клапанами та / або внутрішньовенно поблизу ділянок вен з неспроможними клапанами. При цьому швидкість введення, об'єм та концентрацію розчину перекису водню визначають з урахуванням індивідуальної чутливості пацієнта і місцевої реакції венозних судин. При локалізації неспроможних клапанів вен на кінцівках після інфузії розчинів перекису водню проводять бинтування еластичним бинтом, починаючи з фаланг кінцівок. При лікуванні варикозної хвороби кінцівок також застосовують компрес з настойкою спеціально підібраних лікарських рослин, яка має протизапальну, протинабрякову, антиагрегантну, судинозвужувальну, протизапальну, знеболювальну, антибактеріальну, дезінфікувальну властивості. 
Огляди літератури, оригінальні дослідження, погляд на проблему, ювілеї

В процесі лікування відбувається поступове зменшення рефлюксу біля неспроможних клапанів, звуження варикозно розширених вен, вузлів і повернення їх до нормальних розмірів. Курс лікування складає від 5 до 30 і більше процедур. Приблизна тривалість курсу лікування залежить від ступеня і поширеності патологічного процесу. При лікуванні варикозної хвороби I стадії вона складає до 1-8 сеансів; II стадії - від 8 до 15 сеансів, III стадії - близько 20 сеансів, IV стадії - 20-55 і більше сеансів [19].

Пацієнти суб'єктивно відчувають зникнення больових симптомів, набряків на кінцівках, судом, важкості в ногах. У пацієнтів з варикозним розширенням вен I-III стадії, при переносимості компонентів процедур, отримуємо позитивний результат. 3 метою запобігання виникненню рецидиву захворювання, особливо пацієнтам з ожирінням і пацієнтам, вимушеним тривалий час стояти протягом дня, додатково рекомендоване виконання спеціальної фізичної вправи.

Переваги даного способу відновлення функції неспроможних клапанів вен, порівняно із іншими методами, наступні:

а) лікування проводиться речовиною, яка в нормі виробляється лейкоцитами крові людини і не $\epsilon$ чужорідною для організму;

б) лікування не потребує знеболювання;

в) при правильно підібраних швидкості введення і концентрації розчину перекису водню не відбувається виключення вени або її окремої ділянки і зберігається її функція, що особливо важливо для пацієнтів і дає можливість застосовувати даний спосіб без вікових обмежень, а також на початкових стадіях захворювання;

г) забезпечується максимальний косметичний ефект, без пошкодження м'яких тканин та післяопераційних ускладнень;

д) в процесі лікування відбувається відновлення функції неспроможних клапанів не лише глибоких, а й поверхневих вен, поверхнево-глибоких венозних співусть.

Недоліки даного способу наступні:

а) лікування певної частини пацієнтів може бути досить тривалим (до 60 і більше сеансів);

б) щоб досягти повного відновлення функції клапанів іноді потрібно пройти декілька курсів лікування;

в) після лікування можливий рецидив хвороби, а також не виключена поява нових ділянок варикозної хвороби;

г) наявність певного переліку захворювань і індивідуальної непереносимості розчинів $\mathrm{H}_{2} \mathrm{O}_{2}$ унеможливлюють широке використання даного способу в клінічній практиці.

В науково-медичній і патентній літературі на сьогоднішній день не виявлено даних про анало- гічний спосіб відновлення функції неспроможних клапанів вен поверхневої, глибокої венозної систем, поверхнево-глибоких венозних співусть за допомогою внутрішньовенного введення розчинів перекису водню безпосередньо в ділянки вен з неспроможними клапанами та / або внутрішньовенного введення поблизу ділянок вен з неспроможними клапанами.

Результати та їх обговорення. Запропонований метод ми ефективно використовуємо в практичній роботі впродовж 2003-2018 років. Станом на 01 липня 2018 року спосіб було застосовано у 2653 пацієнтів. Спостереження за вилікуваними пацієнтами протягом 15 років показало високу ефективність цього методу. 50-60 \% потребують підліковування через рік, два, три і більше після завершення основного курсу лікування; дотримання рекомендацій зменшує ризик рецидиву і поширення варикозу. Метод показаний для лікування варикозної хвороби в будь-якому віці при вмілому користуванні і урахуванні протипоказань.

Успішність та ефективність такого лікування можна проілюструвати наступними прикладами 3 практики.

Хвора Л., 41 рік, звернулася на лікування 03.08.2011 року з діагнозом - Варикозна хвороба правої нижньої кінцівки, ХВН ІІ ст. (класифікація за В. С. Савельєвим (Савельєв В. С., 1972)). Скаржилася на наявність розширених вен у ділянці гомілки правої нижньої кінцівки, відчуття тяжкості, розпираючий біль у ногах в стоячому положенні, помірно виражений набряк гомілки в кінці робочого дня та виникнення судом в лежачому положенні. За даними анамнезу, варикозне розширення вен з'явилося 16 років тому, після вагітності, скарги з'явились 10 років тому, мають тенденцію до наростання. Об'єктивно: на правій нижній кінцівці візуалізуються варикозно змінені підшкірні вени. Локалізація вен - проекція великої підшкірної вени та їі бокових гілок на рівні гомілок, виявлено незначний набряк гомілки та пастозність шкірних покривів. УзДС венозної системи нижніх кінцівок від 29.04.2009 року: праворуч: субкомпенсована клапанна недостатність ВПВ; субкомпенсована недостатність остіального клапана правої ВПВ; недостатність перфоранту групи Шермана; недостатність перфоранту групи Кокетта; недостатність перфоранту групи Бойда.

Лікування здійснювали шляхом внутрішньовенного крапельного введення розчинів перекису водню 0,075 \% в об'ємі 300 мл зі швидкістю 4 мл на хвилину у ділянки вен з неспроможними клапанами, попередньо провівши маркування проекції неспроможних клапанів вен під контролем ультразвукового дуплексного сканування. Застосовували бинтування еластичним бинтом. 
Огляди літератури, оригінальні дослідження, погляд на проблему, ювілеї

Впродовж лікування пацієнтка дотримувалася переважно рослинної дієти з мінімальною кількістю солі та цукру. Після 7 процедур візуально відмічено звуження варикозно розширених вен, перестали турбувати тяжкість, розпираючий біль в ногах, набряки, судоми в лежачому положенні. Через 2 роки під час контрольного огляду констатований задовільний стан пацієнтки. Контрольне УЗДС від 30.07.2013 року: праворуч: ВПВ - клапани спроможні; остіальний клапан - спроможний; комунікантні вени (перфоранти) - клапани спроможні. Даний приклад демонструє довготривалий результат запропонованого лікування - покращення і нормалізація функції остіального клапана, клапанів перфорантних вен і ВПВ.

Хвора К., 30 років, звернулась на лікування 01.10.2012 року з діагнозом - Варикозна хвороба, ХВН II ст. за В. С. Савельєвим. Скаржилася на біль у варикозно розширених венах, тяжкість у ногах, набряки під кінець дня, свербіж по ходу вен від гомілки до паху. 3 анамнезу: хворіє на варикозну хворобу з 16-річного віку. Об'єктивно: на правій і лівій нижніх кінцівках наявні розширені і звивисті вени діаметром до 1 см. УЗДС венозної системи нижніх кінцівок від 19.09.2012 року, до лікування: Праворуч: загальна гомілкова вена - виявлений постійний рефлюкс, неспроможність клапанів; ВПВ - постійний рефлюкс, неспроможність клапанів, виявлене неоклюзивне внутрішньопросвітне утворення (ПТФС); підколінна вена - короткочасний рефлюкс; суральні вени - постійний рефлюкс; перфорантні вени: Кокетта, Бойда, Додда, Мея неспроможні. Лікування здійснювали шляхом внутрішньовенного крапельного введення розчинів перекису водню 0,15 \% в об'ємі 200 мл зі швидкістю 5 мл на хвилину у ділянки вен з неспроможними клапанами, після попереднього маркування їх проекції під контролем ультразвукового дуплексного сканування; бинтування еластичним бинтом. Пацієнтка дотримувалася рекомендованої переважно рослинної дієти з мінімальною кількістю солі та цукру. Після проведених 18 процедур візуально було відмічено звуження варикозно розширених вен, скарги практично зникли. Контрольний огляд було проведено через 7 місяців, загальний стан пацієнтки - задовільний. Контрольне УЗДС від 10.04.2013 року: праворуч: загальна гомілкова вена - рефлюкс не виявлений, клапани спроможні; ВПВ - постійний рефлюкс не виявлений, клапани спроможні, не виявлено внутрішньопросвітного утворення; підколінна вена-рефлюкс не виявлений; суральні вени-не описані; перфорантні вени: Кокетта, Бойда, Додда - спроможні; перфорантна вена Мея - неспроможна, тобто потребує додаткового лікування.

Висновки. УЗДС обстеження підтвердили, що запропонований нами спосіб відновлення функції неспроможних клапанів вен сприяє покращенню і відновленню клапанів системи поверхневих вен (ВПВ, МПВ), клапанів поверхневоглибоких венозних співусть (остіальний клапан ВПВ, остіальний клапан МПВ), клапанів глибокої венозної системи (перфорантних вен, загальної гомілкової вени, підколінної вени тощо) у всіх пацієнтів при добрій переносимості розчинів перекису водню.

Запропонований та запатентований нами спосіб відновлення функції неспроможних клапанів вен $\epsilon$ ефективним способом відновлення функції неспроможних клапанів вен при лікуванні варикозної хвороби та для запобігання виникненню її рецидиву. Головними перевагами вказаного методу $є$ його доступність, висока ефективність і безпечність.

\section{ЛІТЕРАТУРА}

1. Михин Н. А. Варикозное расширение вен нижних конечностей / Н. А. Михин // Бюллетень медицинских интернет-конференций. - 2015. - Т. 5, № 5. - С. 65-69.

2. Mechanochemical endovenous ablation of small saphenous vein insufficiency using the ClariVein device: One-year results of a prospective series / D. Boersma, R. R. J. P. van Eekeren, D. A. B. Werson [et al.] // European Journal of Vascular and Endovascular Surgery. - 2013. Vol. 45, Issue 3. - P. 299-303.

3. Шевченко Ю. Л. Основы клинической флебологии / Ю. Л. Шевченко, Ю. М. Стойко, М. И. Лыткин. - М. : Медицина, 2005. - 312 с.

4. Патент RU № 2200487 Способ коррекции относительной клапанной недостаточности глубоких вен нижних конечностей / Самарский межведомственный научно-исследовательский институт «Неионизирующее излучение в медицине». Заяв. 03.20.2003 г.

5. Неумывакин И. П. Перекись водорода / И. П. Неумывакин. - М. : Диля, 2004. - С. 84-86.

6. ДугласУ. Новое о перекиси водорода/У. Дуглас.СПб. : Питер, 2006. - 7 с.

7. Патент №0002201229C1, RU. Способ оздоровления организма / В. А. Миронов. Заяв. 26.03.2002. Опубл. 27.03.2003.

8. Патент №0002235521 C2, RU. Спосо6 лечения каузалгии после ампутации нижних конечностей / Р. Х. Муллахметов; В. А. Ситников; С. Н. Стяжкина. Заяв.18.11.2002. Опубл.10.09.2004.

9. Пат. № 108022 Україна МПК А61К 33/40 (2006.01) А61P 9/14 (2006.01) Спосіб Терновської Т. О. віднов- 
Огляди літератури, оригінальні дослідження, погляд на проблему, ювілеї

лення функції неспроможних клапанів вен / Т. О. Терновська, А. А. Бондаренко, П. А. Терновський ; заявл. 02.10.2013; опубл. 26.01.2015; Бюл. № 5. - 8 с.

10. Аскерханов Р. П. Хирургия периферических вен / Р. П. Аскерханов - Махачкала, 1973- 393 с.

11. Venous valvuloplasty with angioscopy / S. Hoshino, A. Tsuda, H. Satokawa [et al.] // Phlebology. - 1995. Suppl. 1. - P. 949-951.

12. Masuda E. M. Long term results of venous valve reconstruction: A four-to twenty-one year follow-up / E. M. Masuda, R. L. Kistner // J. Vase. Surg. -1994. - No. 19. P. 391-403.

13. Веденский А. Н. Варикозная болезнь / А. Н. Веденский. - Л. : Медицина, 1983. - 200 с.

14. Kistner R. L. Transvenous repair of the incompetent femoral vein valve / R. L. Kistner // J. J. Bergan, Yao J. S. T. eds. Venous problems. - Chicago : Yearbook Medical Publishers, 1978. - P. 492-509.

\section{REFERENCES}

1. Mikhin, N.A. (2015). Varikoznoe rasshyreniye ven nizhnikh konechnostey [Varicose veins of lower extremities]. Byulleten meditsynskikh internet-konferentsyy - Bulletin of Medical Internet Conferences, 5, 65-69 [in Russian].

2. Boersma, D., van Eekeren, R.R.J.P., Werson, D.A.B., van der Waal, R.I.F., Reijnen, M.M.J.P., \& de Vries, J.-P.P.M. (2013). Mechanochemical endovenous ablation of small saphenous vein insufficiency using the ClariVein device: One-year results of a prospective series. European Journal of Vascular and Endovascular Surgery, 45, 3, 299-303.

3. Shevchenko, Yu.L., Stoyko, Yu.M., \& Litkin, M.I. (2005). Osnovy klinicheskoy flebologii [Fundamentals of clinical phlebology]. Moscow: Meditsina [in Russian].

4. Patent RU № 2200487, publykatsiya 03.20.2003 h., zayav. Samarskiy mezhvedomstvennyy nauchno-issledovatelskiy institut "Neyoniziruyushchee izluchenye v meditsyne". Sposob korrektsii otnosytelnoy klapannoy nedostatochnosti glubokikh ven nizhnikh konechnostey [Method of correction of relative valvular insufficiency of deep veins of lower limbs]. [in Russian].

5. Neumivakin, Y.P. (2004). Perekis vodoroda [Hydrogen peroxide]. Moscow: Dylia [in Russian].

6. Duglas, U. (2006). Novoe o perekisi vodoroda [New about hydrogen peroxide]. Saint-Petersburg: Piter [in Russian].

7. Mironov, V.A. Patent №0002201229C1, RU. Sposob ozdorovleniya organizma [A way of improving the body]. Declaring. 26.03.2002. Opubl. 27.03.2003 [in Russian].

8. Patent №0002235521 S2, RU. Mullakhmetov, R.Kh., Sytnikov, V.A., Styazhkina, S.N. Sposob lecheniya kauzalgii posle amputatsii nizhnikh konechnostey [Method of treatment of causalgia after amputation of lower limbs]. Zaiav.18.11.2002. Opubl.10.09.2004 [in Russian].

9. Patent № 108022 Ukraina MPKA61K 33/40 (2006.01) A61P 9/14 (2006.01) Ternovska, T.O., Bondarenko, A.A., Ternovskyi, P.A. Sposib Ternovskoi T.O. vidnovlennia funktsii nespromozhnykh klapaniv ven [Method of Ternovskaya T.O. restoration of the function of insolvent veins]. zaiavl. 02.10.2013; opubl. 26.01.2015; Biul. № 58 p. [in Ukrainian].
15. Савельев В. С. Болезни магистральных вен / В. С. Савельев, Э. П. Думпе, Е. Г. Яблоков. - М. : Медицина, 1972. -440 C.

16. Патент № 46708, UA. Спосі6 Терновської Т. О. лікування варикозного розширення вен кінцівок / Т. О. Терновська, А. А. Терновська, П. А. Терновський ; заяв. 20.11.2009; опуб. 25.12.2009; Бюл. № 24. - 3 с.

17. Флебология : руководство для врачей / под ред. Савельева В. С. - М. : Медицина, 2001. - С. 457-459.

18. Патент № 108550, UA. Спосі6 лікування варикозної хвороби, ускладненої флебітом, тромбофлебітом, за Терновською Т. О. / Т. О. Терновська, А. А. Бондаренко; П. А. Терновський ; заяв. 26.07.2013; опуб. 26.01.2015; Бюл. № 2.

19. Патент № 103987, UA. Спосіб Терновської Т. О. лікування варикозної хвороби дітей / Т. О. Терновська, А. А. Бондаренко, П. А. Терновський ; заяв. 26.07.2013; опуб. 10.09.2013; Бюл. № 17 - 5 с.

10. Askerkhanov, R.P. (1973). Khirurgiya perifericheskikh ven [Surgery of peripheral veins]. Makhachkala [in Russian].

11. Hoshino, S., Tsuda, A., Satokawa, H., Midorikawa, H., Takase, S., Ogawa, T., Igari, T. (1995) Venous valvuloplasty with angioscopy. Phlebology, 1, 949, 951.

12. Masuda, E.M., Kistner, R.L. (1994) Long term results of venous valve reconstruction: A four-to twentyone year follow-up. J. Vase Surg., 19, 391-403 p.

13. Vedenskiy, A.N. (1983). Varikoznaya bolezn [Varicose disease]. L.: Meditsina [in Russian].

14. Kistner, R.L. (1978). Bergan, J.J., Yao, J.S.T. (Eds.). Transvenous repair of the incompetent femoral vein valve. Venous problems. Chicago: Yearbook Medical Publishers.

15. Savelyev, B.C., Dumpe, E.P., \& Yablokov, E.G. (1972). Bolezni magistralnykh ven [Diseases of the main veins]. Moscow: Meditsina [in Russian].

16. Patent № 46708, UA, Zaiav. 20.11.2009 Opub. 25.12.2009 Ternovska, T.O.; Ternovska, A.A.; Ternovskyi, P.A. Sposib Ternovskoi T.O. likuvannia varykoznoho rozshyrennia ven kintsivok [Method of Ternovskaya T.O. treatment of varicose veins of the extremities] [in Ukrainian].

17. Savelyev, B.C. (Ed.). (2001). Flebologiya: rukovodstvo dlya vrachey [Phlebology: a guide for doctors]. Moscow: Meditsina [in Russian].

18. Patent № 108550, UA, Zaiav. 26.07.2013 Opub. 26.01.2015, Biul. № 2 Ternovska, T.O., Bondarenko, A.A., Ternovskyi, P.A. Sposib likuvannia varykoznoi khvoroby, uskladnenoi flebitom, tromboflebitom, za Ternovskoiu T.O. [Method of treatment of varicose disease, complicated by phlebitis, thrombophlebitis, according to Tearnovskaya T.O.]. [in Ukrainian].

19. Patent № 103987, UA, Zaiav. 26.07.2013. Opub. 10.09.2013, Biul.№ 17 Ternovska, T.O., Bondarenko, A.A., Ternovskyi, P.A. Sposib Ternovskoi T.O. likuvannia varykoznoi khvoroby ditei [Method of Ternovskaya T.O. treatment of varicose veins of children]. [in Ukrainian]. 
Огляди літератури, оригінальні дослідження, погляд на проблему, ювілеї

\title{
ИСПОЛЬЗОВАНИЕ МЕТОДА ВНУТРИВЕННОГО ВВЕДЕНИЯ РАСТВОРОВ ПЕРЕКИСИ ВОДОРОДА ДЛЯ ЛЕЧЕНИЯ ПАЦИЕНТОВ С ВАРИКОЗНЫМ РАСШИРЕНИЕМ ВЕН НИЖНИХ КОНЕЧНОСТЕЙ
}

\author{
๑Т. А. Терновская ${ }^{1}$, А. А. Бондаренкоㄹ, П. А. Терновский² \\ МОз Украины, Медицинский кабинет \\ Частный предприниматель Терновская Тамара Алексеевна, г. Кропивницкий \\ Донецкий национальный медицинский университет²
}

РЕЗЮМЕ. Варикозная болезнь нижних конечностей известна издавна, однако и сегодня она остается чрезвычайно актуальной и значительно ухудшает качество жизни пациентов.

Цель - сделать краткий обзор предложенного нами метода лечения варикозного расширения вен с целью восстановления функции несостоятельных клапанов вен. На конкретных клинических случаях показать эффективность и доступность предложенной методики в медицинской практике.

Материал и методы. Диагностику проводили с использованием аппарата для ультразвукового дуплексного сканирования нижних конечностей My Lab 40, для лечения применяли метод введения раствора перекиси водорода по разработанной нами методике [9]; результаты анализа источников отечественной и зарубежной научной литературы и зарегистрированных патентов.

Результаты. Положительный результат лечения конкретных пациентов подтвержден методом ультразвукового дуплексного сканирования (УЗДС). Клинические результаты лечения больных варикозным расширением вен подтверждают возможность использования данного метода, наряду с другими щадящими методами лечения варикозной болезни, в клинической практике.

Выводы. Предложенный и запатентованный нами способ восстановления функции несостоятельных клапанов вен является эффективным для лечения пациентов с варикозным расширением вен и предотвращения возникновения рецидива заболевания. Лечение по нашему методу дает прогнозируемые положительные результаты при умелом пользовании и учете противопоказаний.

КЛЮчЕВЫЕ СЛОВА: варикозное расширение вен; лечение; клапаны вен; перекись водорода.

\section{USE OF METHOD OF INTERNAL INTRODUCTION OF HYDROGEN PEROXIDE SOLUTION FOR TREATMENT OF PATIENTS WITH VARICOSE VEINS OF LOWER LIMBS}

\author{
T. O. Ternovskaya ${ }^{1}$, A. A. Bondarenko², P. A. Ternovsky² \\ Ministry of Health of Ukraine \\ Private entreneur Ternovska Tamara, Kropyvnytskyi ${ }^{7}$ \\ Donetsk National Medical University²
}

SUMMARY. The varicose veins of the lower extremities have long been known, but today it remains extremely relevant and significantly impairs the quality of life of patients.

The aim is to give a brief overview of our proposed method of treating varicose veins to restore the function of unstable veins. On concrete clinical cases, to demonstrate the effectiveness and accessibility of the proposed method in medical practice.

Material and Methods. Diagnosis was performed using a device for ultrasound duplex scanning of lower extremities My Lab 40, for the treatment of the method of introducing a solution of hydrogen peroxide according to the method we developed [9]; results of analysis of sources of domestic and foreign scientific literature and registered patents.

Results. Positive result of treatment of specific patients, confirmed by ultrasound duplex scan (UDF). Clinical results of treatment of patients with varicose veins confirm the possibility of using this method, along with other gentle methods of treating varicose veins, in clinical practice.

Conclusions. The proposed and patented way to restore the function of unstable veins is effective in treating patients with varicose veins and preventing recurrence of the disease. Treatment according to our method provides predictable positive results with skillful use and taking into account contraindications.

KEY WORDS: varicose veins; treatment; vein valves; hydrogen peroxide. 